\title{
SVOTA ZAPADNE NOVOŠTOKAVŠTINE U HRVATSKOME STANDARDNOM JEZIKU
}

Stjepan Vukušić

Kumičićeva 8

HR 52000 Pula
UDK: 811.163 .42

Izvorni znanstveni članak

Ur.: 2016-10-22

U uvodnome dijelu dana su načela zapadne novoštokavštine u naglašavanju. U razradi se izlaže postupno otkrivanje i tumačenje zapadne novoštokavštine. U zaključku se, napokon, donose ishodi uvoda i razrade iz kojih je jasno kako se osvješćivala zapadna i istočna novoštokavština te da na temelju prve imamo sve u jeziku i sav jezik, a drugoj kao sustavu ništa ne dugujemo.

Ključne riječi: novoštokavština - zapadna, istočna, naglašavanje, naglasna norma, hrvatski standardni jezik

\section{Uvod}

Ovaj će tekst ponegdje zazvučati pro domo u užem i širem značenju toga latinskoga diktuma. Neka mi se ovdje oprosti. Posrijedi je još jedno buđenje nakon povijesne mamurnosti - i za hrvatski standardni (i književni) jezik. U prohujalome košmaru djeluju imperijalne sile i pogrješni putovi slavistike, autoriteti nasuprot jezičnoj neprestižnosti i slabim glasovima (koji se i ne čuju), monoliti prema zakopanom blagu. Svega tu ima, a još se i danas vuku repovi tih mutnih, ali srećom i borbom iščezlih vremena koja su htjela slomiti ili bar zatomiti svu našu uspravnost i samosvijest.

I napokon treba i ovdje s dopunom navesti kako valja spoznati i prihvatiti spoznaje:

- da dosad u novoštokavskome kompleksu uistinu postoje dvije popisane i opisane, a na kraju i propisane novoštokavštine: zapadna i istočna;

- da su te dvije novoštokavštine ishodi apstraktne novoštokavizacije kao idealnog pravila i konkretne novoštokavizacije kao primjene toga općeg pravila na različite idiome iz monotonijskoga dvonaglasnog razdoblja;

- da otuda slijede novoštokavske podudarnosti i različitosti; 
- da su obje te sastavnice sustavotvorne i dane u neponovljivome suodnosu u zapadnoj i istočnoj novoštokavštini;

- da je sve to u nama u obliku reprezentacija kao mentalnih struktura ${ }^{1}$ te kao odslik jezgre distinktivne masa glasa;

- da je svaki naglasak ili naglasno počelo drugog sustava rijetko stilem, a najčešće pogrješka;

- da bez zapadnog dijalekta $\mathrm{i}$ istosmjernosti drugih hrvatskih idioma do zapadnonovoštokavskih konačnica hrvatski standardni jezik nema svoje naglasne norme;

- da u uvjetima naše tronarječnosti treba očekivati opće inovacije i konvergentnu osmotsku evoluciju hrvatskoga standardnog i književnog jezika;

- da su temeljni odrazi jata ( |i $\mid$, |ije|je|, |e|) samo izvanjski znakovi za tip novoštokavštine;

- da u skladu s tim postoji i ikavska, tj. zapadna novoštokavština;

- da su čak i odrazi dugoga i produženog jata u hrvatskome jeziku riješeni na ikavski, zapadnonovoštokavski način: jednosložnost na odsječnom i istonaglasnost na nadodsječnom planu: svît je postalo svïjêt, díte - dijéte, üvīk - uvijjēk;

- da između odsječnoga i nadodsječnog plana nije zrakoprazn prostor, nego umreženost naglasaka u sve razine jezičnog opisa, pa naglašavanje seže $u$ sintagmatiku i paradigmatiku, a time i u sintaksu, u tvorbu riječi i leksik.

Za svoj povijesni temelj sa zahvalnošću uzimljemo riječ i misao našega najvećeg jezikoslovca i filologa Vatroslava Jagića: "Ne mislim da će mi se moći išta prigovoriti, kada proglasim ikavski najbitnijom razlikom narječja zapadnoga (hrvatskoga) prema ekavskom, istočnom (srbskom), dočim južni jekavski izgovor držim simbolom združenja i pomirenja. Narječje je štokavsko-ikavsko, zapadno, a ja bih, ali samo kao filolog rekao, hrvatsko."2

Ovdje valja reći da jesam za izbor jekavice kao standardnoga izgovora u hrvatskome jeziku, ali u onome smislu kakav je u prethodnome tekstu: jekavica je, naime, samo izvanjski znak za tip novoštokavštine, tj. samo odraz jata, ali ne i sva jekavska novoštokavština, koja u cjelini nije nigdje opisana. A sve je to znao ili samo genijalno slutio lingvist Jagićeva formata. Međutim, ijekavski izgovor jest definiran u Karadžića i Daničića, ali je taj kao trofonemni dvosložni

\footnotetext{
${ }^{1}$ R. MATASOVIĆ, 1997, 45.

${ }^{2}$ V. JAGIĆ, 1864.
} 
izgovor s uvijek kratkim e s gledišta hrvatskoga jezika neprihvatljiv jer bi zadirao u odsječni plan (dvosložnost) i u nadodsječni (neistonaglasnost). To je dokazao i Dalibor Brozović s obzirom na odraze dugoga i produženog jata ${ }^{3}$, ali s tim autorom nisam suglasan da su ikavci takav izgovor naučili od jekavaca. Podrijetlo je toga izgovora posve drugačije. Ikavci su jekavicu samo prilagodili svomu izgovoru, sačuvavši i tu svoje naglašavanje i ritam: u nadodsječnom planu istonaglasnost, a na odsječnome pak jednosložnost, kako uostalom već i rekosmo.

Pedesetih i šezdesetih godina prošloga stoljeća još je sve u znaku istočne novoštokavštine: Brabec - Hraste - Živković Gramatika hrvatskosrpskoga jezika i Pravopis iz 1960. godine . $^{4}$ "Tako onda (u tom Pravopisu, S. V.) čitamo: vúći i vûći, dovúći i dòvūći, dóći i dôći, nadíći i nàdīći; növ - növa i nòva, öštar - öštra i òštra. Pritom je veoma čudno što nisu zapisani i likovi dvosložnoga pridjeva radnog u obliku za ženski rod, npr. nema vûkla, zêbla, trêsla, a još je čudnije što nema naglasaka tipičnih za hrvatski jezik u glagola s kratkom osnovom, pa je u Pravopisu samo pèći, plèsti, tèći. Vrhunac je, međutim, prozodijske nedosljednosti u Pravopisu što u prefigiranih glagola izlètjeti itd. sustavno nalazimo samo uzorak dolètīm ... doletímo i dolètīmo, doletíte i dolètîte. Na prvome su mjestu u zagrebačkom, latiničnom, (i)jekavskom, dakle hrvatskom izdanju naglasni likovi koji se u hrvatskome književnom jeziku nikako ne ostvaruju ako se izuzme prijevod kakva klasičnog teksta, gdje je takav naglasak uzet iz metričkih razloga."6

Onda slijedi pravi zaokret i u priručnicima. Prvi je takav Priručna gramatika hrvatskoga književnog jezika (1979.) autorā Eugenije Barić, Mije Lončarića, Dragice Malić, Slavka Pavešića, Mirka Petija, Vesne Zečević i Marije Znike, Školska knjiga, Zagreb, Zavod za jezik Instituta za filologiju i folkloristiku.

Čitam nasumce iz navèdene gramatike: nàrāsti i narásti, plësti i plèsti, ìsplesti i isplèsti; vûći (i vúći), têći (i tèći), plësti (i plèsti).

Prvi put u povijesti hrvatskoga standardnoga jezika nalaze se u jednoj gramatici u tzv. dubletama ${ }^{7}$ hrvatski uporabni, zapadnonovoštokavski naglasci na prvim mjestima. A dalje polèžati - polèžīm, izvíždati - izvíždīm, zatrúbiti zatrúbīm nesustavno je jer bi trebalo u prezentu: pòležìm, ìzvīždīm, zàtrūbīm kad

\footnotetext{
${ }^{3}$ D. BROZOVIĆ, 1972.-73.

${ }^{4}$ I. BRABEC - M. HRASTE - S. ŽIVKOVIĆ, 1965.

${ }^{5} \mathrm{MH}$ i MS, Zagreb - Novi Sad

${ }^{6}$ S. VUKUŠIĆ - I. ZORIČIĆ - M. GRASSELLI-VUKUŠIĆ, 2007, 19.

${ }^{7}$ Tzv. dublete, jer su stvarne $\mathrm{u}$ istome sustavu.
} 
se već promovira zapadno novoštokavsko naglašavanje. Čitam i dalje: cr̂psti i cŕpsti, nâći i náći; plëo - plëla i plèla, plëlo i plèlo, plëli i plèli, plële i plèle; möći (i mòći). Ovo je doista priručnički, naime gramatički novum, pravo razmeđe razdoblja do šezdesetih godina i novoga od kraja sedamdesetih do danas, u kojem nijedan priručnik više ne će biti bez zapadnoga novoštokavskog naglašavanja. I sve će postupno rasti u njegovu korist u novim priručnicima sve do samog VRH-a, tj. Velikog rječnika hrvatskoga standardnog jezika u izdanju Školske knjige, Zagreb, 2015. Ovaj je posljednji u promociji zapadnoga novoštokavskog naglašavanja najiscrpniji. I po tome se taj rječnik doimlje kao svota naše bogate rječničke djelatnosti posljednjih desetljeća.

\section{RAZRADBA}

Naglaske sam naučio u svojoj podgorskoj obitelji iz Stinice, to jest iz Živih Bunara. A dugo nakon toga doznao sam kako je to naglašavanje akcentuacija stiničkoga govora.

Za svojega zagrebačkog studija osvijestio sam četiri osnovne naglasne jedinice ${ }^{8} \mathrm{~s}$ jednom nenaglašenom kratkoćom i jednom zanaglasnom dužinom u svemu šest prozodijskih vrijednosti i njihov općerazdiobni propis.

Za naglasnu sam vježbu kod profesora Jonkea uzeo Heronejskog lava S. S. Kranjčevića. Sve sam, mislim, dobro iznaglašavao, ali se tu "heronejski" suprotstavlja razdiobnom pravilu da se silazni naglasci ne mogu naći na srednjim i posljednjim slogovima. Nameće mi se, naime, samo "heronêjskī". Tad još nisam znao da tuđice postaju usvojenicama kad se i naglasno prilagode novoštokavskomu sustavu. Jamačno bih i danas bio glede nekih tuđica u naglasnoj nedoumici. Najdalje je u njihovoj novoštokavizaciji stigao upravo izašli Veliki rječnik hrvatskoga standardnog jezika. A što se tiče moje vježbe kod profesora Jonkea, sve je uglavnom išlo napamet. Mislim da sam i u kasnijim pomacima sačuvao nešto od toga napametnoga načela.

Profesor mi je Hraste tad zadao: da sve osobne zamjenice naglasim u njihovim paradigmama po svojemu polaznome jeziku. Poslije me je uputio profesoru Stjepanu Ivšiću. S njegovim akutom nakon mnogo vremena proniknut ću uzorak:

potrēstï $>$ potrẽst $>$ potrêst $>$ pòtrēst $>$ pòtrēsti. Od dva posljednja lika prvi je organski novoštokavski, a drugi standardan za hrvatski jezik.

8 Četiri osnovne naglasne jedinice jesu: dugosilazni naglasak ( ` ), kratkosilazni ( " ), dugouzlazni (' ) i kratkouzlazni ( ' ). Drugo su sustavne jedinice, npr. vòjnīk - vojníka. 
Tek na Pedagoškoj akademiji u Puli (poznijem Filozofskom fakultetu) šezdesetih godina prošlog stoljeća predajem naglasnu tipologiju i ne mogu se načuditi koliko se ta razlikuje od mojega, također novoštokavskoga naglašavanja.

Odakle je to i dokle seže u prostor i vrijeme, trebalo je postupno doznavati.

Vodi me slutnja da su posrijedi dvije novoštokavske akcentuacije. No glavno je biti na pravome putu. Uđeš li u krivo prometalo, sve su postaje pogrješne.

Što se tiče puta u dijalektne prostore, treba pozorno birati prave obavjesnike, a glede dijakronije sve je u unutarnjoj povijesti jezika. I teorija je potrebna. A ona će se postići ustrajnim domišljanjem te pridruživanjem novih znanja i spoznaja već poznatom.

Ubrzo utvrdih da se moje stiničko naglašavanje u bitnome širi u sve govore zapadnog ikavskog dijalekta, a razlikuje se od Karadžić - Daničićeve akcentuacije.

Već u prvoj polovici sedamdesetih godina objavljen je u Jeziku moj prvi članak iz akcentologije "Naglasci uporabne norme na osnovi startnog jezika". U zaključku toga članka piše: "Ukratko, što se tiče naglaska u glagola, novoštokavski ikavci imaju svoju uporabnu normu na osnovi svoga startnog jezika."

U drugome članku "Usporedbe dvaju novoštokavskih naglašavanja imenica muškog roda na -Ø"9 već prva rečenica glasi: "U ovom se radu uspoređuju dva novoštokavska naglašavanja: Daničićevo s jedne i zapadno novoštokavsko naglašavanje s druge strane." Dakle, zapadna je novoštokavština istaknuta već 1976. godine.

Stjepan Babić u Napomeni uz prethodni članak piše: "Članak S. Vukušića pokreće važnu problematiku u normi hrvatskoga književnog jezika. Dosad je hrvatska akcentologija vrludala između jedne teorije i druge prakse". U toj Napomeni Babić je Daliboru Brozoviću galantno poklonio prekretničku ulogu, ali se pokazalo da Brozović nije za prekretnicu, a Stjepan Babić jest.

Sve se to znatno produbilo kad sam spremao doktorat s temom "Usporedbe dvaju novoštokavskih naglašavanja - stiničkog i Daničićeva - Prilog za uporabnu normu hrvatskoga književnog jezika". ${ }^{10}$

Prije svega trebalo je utvrditi da je stinički govor konkretan organski idiom s određenim granicama i obilježjima, posebice naglasnim, tj. da se baš po

9 S. VUKUŠIĆ, 1975. 92-118.

${ }^{10}$ S. VUKUŠIĆ, 1982, 283-366. 
tome razlikuje od susjednih govora - starigračkog i prižanjskoga. "Stinički je govor jedan od podgorskih govora, tj. od govora Podgorja, a ti su govori onaj dio zapadne ikavske novoštokavštine koji zauzima prostor primorske padine Velebita od Senja i Senjske Drage na sjeverozapadu do Novigradskog mora na jugoistoku. Podgorski govori zajedno s ličkim zapadnonovoštokavskih govorima i onima u senjskom zaleđu i dijelu Gorskog Kotara čine najzapadniji dio novoštokavskoga ikavskog dijalekta."11

Naglasno je obilježje stiničkoga govora dosljedan i prilagođen dugouzlazni naglasak u genitivu množine naglasne jedinice vránac, dakle vránācā, žívācā; písāmā, drúštāvā. Tomu valja dodati i genitiv množine Bosánācā, Dalmatínācā, Amerikánācā. ${ }^{12}$

U stiničkom govoru našao sam novi naglasni sustav koji je u bitnome istovjetan cijelomu zapadnom ikavskom dijalektu, a u mnogome različit od onoga Karadžić - Daničićeva. K tomu sam utvrdio i istosmjernost naglasnoga razvoja brojnih hrvatskih idioma do novoštokavskih konačnica, koje se naglasno razlikuju od Karadžić - Daničićeva istočnonovoštokavskoga naglašavanja.

U tome smislu navodim sljedeće razvojne tijekove:

\begin{tabular}{|c|c|c|c|c|c|}
\hline $\begin{array}{l}\text { Senj } \\
\text { (čakavski } \\
\text { dijalekt) }\end{array}$ & $\begin{array}{l}\text { Posavina } \\
\text { (ikavski } \\
\text { govori) }\end{array}$ & $\begin{array}{l}\text { Istra } \\
\text { (jugozapadni } \\
\text { dijalekt) }\end{array}$ & $\begin{array}{l}\begin{array}{l}\text { Stinica } \\
\text { (novoštokavski } \\
\text { govori) }\end{array} \\
\end{array}$ & $\begin{array}{l}\text { Standardni } \\
\text { hrvatski jezik }\end{array}$ & $\begin{array}{l}\text { Karadžić - } \\
\text { Daničićevi } \\
\text { likovi }\end{array}$ \\
\hline trẽst & trêst & trêst(i) & trêst & trêsti & trésti \\
\hline rasplëst & $\begin{array}{l}\text { oplëst } \\
\text { i òplest }\end{array}$ & istëć(i) & $\begin{array}{l}\text { ìsteć } \\
\text { òplest }\end{array}$ & $\begin{array}{l}\text { ìsteći } \\
\text { òplesti }\end{array}$ & \begin{tabular}{|l|}
$\begin{array}{l}\text { istèći } \\
\text { oplèsti }\end{array}$ \\
\end{tabular} \\
\hline otrẽst & otrêst & povûć(i) & $\begin{array}{l}\text { pòvūć } \\
\text { òtrēst }\end{array}$ & pòvūći òtrēsti & povúći otrésti \\
\hline stojẽć & gorẽć & $\begin{array}{l}\text { gorêć(i) } \\
\text { letêć(i) }\end{array}$ & $\begin{array}{l}\text { gòrēéc } \\
\text { lètēé }\end{array}$ & $\begin{array}{l}\text { gòrēći } \\
\text { lètéći }\end{array}$ & letéći \\
\hline ispëkla & utëkla & istëkla & $\begin{array}{l}\text { ìstekla } \\
\text { ùtekla } \\
\text { ìspekla }\end{array}$ & $\begin{array}{l}\text { ìstekla } \\
\text { ùtekla } \\
\text { ìspekla }\end{array}$ & $\begin{array}{l}\text { istèkla } \\
\text { utèkla } \\
\text { ispèkla }\end{array}$ \\
\hline izgörin & $\begin{array}{l}\text { dolëti } \\
\text { dòletī }\end{array}$ & odlëti & \begin{tabular}{|l|} 
òdletī̄ \\
dòletī
\end{tabular} & $\begin{array}{l}\text { òdletī } \\
\text { dòletī }\end{array}$ & \begin{tabular}{|l|} 
izgòrī \\
dolètī
\end{tabular} \\
\hline dožĩvin & dožîvi & ožîvi & $\begin{array}{l}\text { dòžīivi } \\
\text { òžīivi }\end{array}$ & $\begin{array}{l}\text { dòžīvī } \\
\text { òžīivi }\end{array}$ & $\begin{array}{l}\text { dožívī } \\
\text { ožívī }\end{array}$ \\
\hline
\end{tabular}

${ }^{11}$ S. VUKUŠIĆ, 1982, 286.

${ }_{12}$ Nakon određenih kolebanja priručnici su prihvatili i prilagođeni lik Dalmatínācā uz preneseni Dalmàtīnācā, a spikeri Radio Zagreba u većini izgovaraju: vatrogásācā, policájācā, poslodávācā itd. 
Što nam pokazuje to kratko usporedno oprimjerivanje?

- Da se razlikuju geneze, sustavi inorme zapadnog i istočnog novoštokavskog naglašavanja;

- da na temelju glasovno - obličnih ustrojstava imamo istosmjerni razvoj do hrvatskih standardnojezičnih konačnica, odnosno da je posrijedi u srpskome jeziku druga geneza, sustav i norma;

- da je po tome zapadni novoštokavski dijalekt srodniji ostalim hrvatskim idiomima nego istočna novoštokavština;

- da postoji razvojni smjer: akut (otrẽsti) $>$ dugosilazni (otrêst) $>$ organski novoštokavski lik (òtrēst), standardni novoštokavski lik (òtrēsti); pëkla, ispëkla > ìspekla (i organski i standardnojezični lik);

- da je ovdje konkretizirano opće pravilo apstraktne novoštokavizacije koje pada na različite idiome iz prednovoštokavskoga razdoblja.

Postoje, naime, dvije novoštokavizacije: apstraktna po općem pravilu i konkretna po ostvarivanju toga pravila na različitim prednovoštokavskim idiomima. Obje se ostvaruju istodobno, pa njima nastaju općenovoštokavske podudarnosti, gdje su se u različitim idiomima nalazili i prije novoštokavizacije isti likovi, a gdje su se likovi razlikovali, nastaju konkretni novi likovi, sad preznakovljeni u duhu općeg pravila.

Ikavski je izgovor, npr., stariji od novoštokavizacije, pa u glagola koji su promijenili stari jat sa -it(i) imaju sad iste likove kao i oni što su otprije imali -it(i): poželït(i) - požělīm kao polomìt(i) - polömīm, a pri drugoj osnovi: dožīvìt(i) - dožîvīm kao obālčìt(i) - oblâčīm... I to je samo pars pro toto budućih naglasnih jedinica u novoštokavskome sustavu.

Novoštokavizacijom se pomiču silazni naglasci sa srednjih i posljednjih slogova za jedan slog prema početku riječi pri čemu se na kratkom slogu ostvaruje kratkouzlazni naglasak, a na dugom slogu dugouzlazni s tim da na slogu s kojega je prenesen dugosilazni naglasak ostaje zanaglasna dužina, pa se od prethodnih likova dobiju novi: požèlit - pòželīm kao polòmit - pòlomīm; u dugim osnovama dožívit - dòžīivīm kao obláčit - òblāčīm. Standardni su likovi dakako požèljeti - pòželīm kao polòmiti - pòlomīm, dožívjeti - dòžīīim kao obláčiti - òblāčīm. Dakle, ikavska je zamjena jata kao inovacija izazvala i naglasne inovacije jer su se glagoli koji su stekli -it(i) ikavskom zamjenom jata naglasno poistovjetili s onim glagolima koji su i prije odrazā jata imali infinitivni završetak it(i). Vidi se to i danas: jekavskom zamjenom jata u standardnome jeziku nije se ništa dogodilo u nadodsječnom planu. Naglasci kakvi su utvrđeni u sustavu, nisu lako podložni mijenama kao da je u njima i nešto više nego smo navikli misliti. I sama jekavska zamjena dugoga jata riješena je na ikavski način: jednosložnost 
na odsječnom planu, a istonaglasnost na nadodsječnome: tîsan - ẗjêsan, díte dijéte, üvīk - üvijēk.

Naglasni odnosi kakvi su u glagola dožívjeti - dòžīvīm i požèljeti - pòželīm vrijede i za one glagole koje je Stjepan Babić uveo u petu glagolsku vrstu zbog završetka -ati i prezentskih nastavaka -īm, -1̌š itd., a morf im - a - stoji prema starom jatu iza glasova č, j, š, ž i glasovnih skupina št, žd: pobòjati se - pòbojīm se, zakrìčati - zàkričīm, zazvíždati - zàzvī̌̌dīm, zazújati - zàzūjīm.

To je tek jedan od glasovno - obličnih uzroka naglasnih promjena. Drugi je gubitak -i u infinitivu, kako pokazuje i naša usporedna egzemplifikacija. U cijelosti se mogu navesti uzorci:

\begin{tabular}{|c|c|}
\hline Izvorni likovi & Standardni likovi \\
\hline tëći $>$ tëć $>$ tëć & tëći \\
\hline potećï $>$ potëć $>$ pòteć & pòteći \\
\hline vūćí > vũć > vûć & vûći \\
\hline povūćî > povũć > povûć > pòvūć & pòvūći \\
\hline
\end{tabular}

I ovdje su uzorci svojevrstan pars pro toto.

I tu mi pada na pamet Jonkeova duboka slutnja koju je izrazio riječima: "intenzivna prijenosna akcentuacija". To vrijedi i za:

1. dòžīvīm

2. dògorīm

3. pòležīm

4. zàzūjīm

5. pòteći - pòtekla

6. pòvūći - pòvūkla

7. zà mene (i za mëne)

8. lètēći

9. 1. i 2. mnž. osoba prezenta lètīmo lètīte prema letímo, letíte (istočno).

I autonomni je razvitak samih naglasnih sustava prouzročio određene razlike: čěšalj - čěšlja prema čěšalj - čěšlja (i čěšlja, istočno), vòće prema vöće (istočno), köplje prema kòplje (istočno). Takve su razlike rasute po cijelom leksiku, a izraz su prestrojavanja među naglasnim jedinicama. Ovamo idu i kosi padeži brojeva: dvâ, trî, G dvàjū, trìjū, DLI dvàma, trìma. Također su od brojeva öba, öbadvā, dvïje, öbje, öbadvije genitivi obàjū, obadvàjū, obìjū, 
obadvìjū, a DLI obàma, obadvàma, dvjèma, objèma, obadvjèma. Tu se prema kratkouzlaznom naglasku u zapadnoj novoštokavštini javlja u kosim padežima dugouzlazni u istočnoj.

Sve to pokazuje kako je ikavica kao znak raspoznavanja tipa novoštokavštine zasvagda iščezla iz hrvatskoga standardnog jezika, ali je u njemu ostavila svoj neizbrisiv trag. Te su inovacije s autonomnim razvojem samoga naglasnog sustava promijenile i naglašavanje unutar novoštokavštine. Zato smatram promašenim Brozovićevo navođenje svih novoštokavskih dijalekata na dijalektološkoj karti kao samo jednoga gigantskog dijalekta. ${ }^{13} \mathrm{Na} 106$. stranici svojega Standardnog jezika D. Brozović piše: "Izuzmemo li odsutnost nenovoštokavskih osobina, nenovoštokavski dijalekti nemaju ni zajedničkih osobina ni zajedničke fizionomije, a novoštokavski imaju i jedno i drugo."14 To mišljenje demantira u cijelosti naša prethodna razvojna egzemplifikacija. Sve pozicije razlika Brozović smatra supstancijom, a nipošto strukturom, a one izrastaju iz razvojnih inovacija u dijakroniji te potječu iz distinktivne mase glasa u sinkroniji. A Ž. Muljačić piše u Osnovama dijakronične fonologije "da se i najmanje promjene odražavaju na dijelove sistema u kojem se zbivaju, a ponekad i na cijeli sistem." ${ }^{15}$ I sve je u jeziku sustav i struktura, tj. forma, a supstancija je samo tvarni aspekt jezične građe, ono u čemu se jezik kao oblik očituje. To je po Hjelmslevu predmet fizike, a ne lingvistike.

Vuk Stefanović Karadžić također ne zna ili ne pozna zapadni ikavski dijalekt jer ga u njegovu Srpskom rječniku iz 1818. nema. Dok ga u izdanju iz 1852. doduše uvodi, ali ga svodi na ikavski izgovor staroga glasa jata, a pod zapadno piše samo svoje naglaske. A Dalibor Brozović opčinjen je srpskim jezikoslovcima, dok su oni opčinjeni svojim imenom. A tko to zna je li ikad postojala novoštokavska folklorna koine u prilikama vječnoga rata i bijega na zapad, sjever, jug. Ako je i postojala, u njoj su bila sva ona račvišta s inovacijama što ih Brozović naziva jedne supstancijom, druge strukturom, a pritom iscrtava na svojim dijalektološkim kartama jedan gigantski novoštokavski dijalekt kao moguću podlogu novoštokavske folklorne koine koja da bi bila onaj jezik što ga je utemeljio Vuk Stefanović Karadžić i Đuro Daničić. Karadžić jest dopunjavao i popunjavao svoje prvo izdanje Srpskoga rječnika, ali opet ne toliko da bi u drugom izdanju (1852.) uzeo išta od naglašavanja zapadnog ikavskog dijalekta jer je imao u vidu samo svoje tršićke naglaske. Pavle Ivić u svojoj knjizi Srpski

\footnotetext{
${ }^{13}$ D. BROZOVIĆ, 1970, 158.

${ }^{14}$ D. BROZOVIĆ, 1970, 106.

${ }^{15}$ Ž. MULJAČIĆ, 1972, 194.
} 
narod i njegov jezik (1971.) piše: "Vukovo prvo izdanje je u osnovi rečnik govora jednog čoveka." ${ }^{16}$ Gdje je tu novoštokavska folklorna koine i jedan gigantski novoštokavski dijalekt kao njezina podloga?

Zapadna je novoštokavština veliki prinos hrvatskomu književnom jeziku. Sve je započelo pred više od sto godina s Grgom Tomljenovićem ${ }^{17}$ i Milanom Japunčićem ${ }^{18}$, a konačno se utvrdilo i zaokružilo u nekoliko posljednjih desetljeća.

Već su spomenuta dva članka u Jeziku. U radu "Naglasci uporabne norme na osnovi startnog jezika" već je istaknuta uporabna norma kao otkrivanje zakopanog blaga, a drugi članak iz 1976. godine sadrži novi naziv zapadno novoštokavsko naglašavanje. Ivan Zoričić piše u Predgovoru Usporedba dvaju novoštokavskih naglašavanja - stiničkog i Daničićeva: "Pisac vodi čitaoca od stiničkoga naglašavanja, preko naglasnih podudarnosti u drugim govorima zapadnog dijalekta, do spoznaje da je to naglašavanje preraslo granice svoga idioma i ušlo u književni jezik, u njegovu uporabnu naglasnu normu." 19

Slijedi knjiga Nacrt hrvatske naglasne norme na osnovi zapadnog dijalekta $(1984 .)^{20}$, o kojoj Milan Moguš piše: "Na diskrepanciju između uporabne i književne naglasne norme upozorili su ranije i drugi, npr. Grga Tomljenović i Milan Japunčić o kojima se ovdje također raspravlja kao o pretečama ovakva posla, ali je Vukušić prvi proširio istraživanja na cijeli sustav, razmotrivši gotovo svaki sporni slučaj u nizu rasprava skupljenih ovdje u knjizi. Stoga je ovo ne samo prvi nego i pravi pokušaj da se na osnovi obilne građe sustavno izloži problematika. U tom smislu ovaj Vukušićev Nacrt jest temelj."21

To se poimanje sukobilo s Brozovićevim pogledima na izvorišta naglasne norme hrvatskoga standardnoga jezika, pa je to daljnji tijek otežalo i usporilo.

Na razmeđu dvaju stoljeća i dvaju tisućljeća, za vrijeme ispita u kabinetu pulske kroatistike zazvonio je telefon. Iz Nakladnog zavoda Globus javio se njegov upravitelj Tomislav Pušek. Izrazio je naum da bi Nakladni zavod Globus bio pripravan objaviti rukopis našeg projekta (koji je ležao već devetu godinu u Razredu za filologiju HAZU). I to kao Knjigu četvrtu Velike hrvatske gramatike. Tad sam rekao gospodinu Pušeku da bi to bio vrlo sretan most između inercije

\footnotetext{
${ }^{16}$ P. IVIĆ, 1971, 283.

${ }^{17}$ G. TOMLJENOVIĆ, 1911

${ }^{18}$ M. JAPUNČIĆ, 1912.

${ }^{19}$ S. VUKUŠIĆ, 1982.

${ }^{20}$ S. VUKUŠIÍ́, 1984.

${ }^{21}$ S. VUKUŠIĆ, 1984, 7.
} 
Akademijina Razreda za filologiju i naše težnje da se ostvari naglasna norma hrvatskoga jezika na osnovama zapadne novoštokavštine.

Predao sam rukopis gospodinu Tomislavu Pušeku, trajno držeći da ga je o njegovoj kakvoći što se tiče naglaska obavijestio akademik Stjepan Babić.

Slijede radni susreti između gospodina Pušeka i mene kao nositelja projekta te moje supruge kao suautorice: na Velebnom, kamo mi je budući izdavač Velike hrvatske gramatike donio kritiku Dalibora Brozovića, ispisanu na rubnicima teksta. Tu se nalazio cijeli splet uzajamnih nesuglasja između Dalibora Brozovića i mene. Međutim, Tomislav Pušek, upravitelj Nakladnog zavoda Globus, rekao nam je da će knjiga sigurno biti objavljena. Vjerovali smo tomu čovjeku. A to je bilo i jedno od mojih najboljih iskustava s izdavačima. Slijedili su susreti u Lovranu, Labinu i Puli. Tomislav Pušek htio je svakako objaviti knjigu, pa mu je to nalagalo da se opskrbi mišljenjem i pomoći brojnih jezikoslovaca. Tko bi znao s kim se nije savjetovao da bi knjiga bila što bolja.

Napokon je 7. siječnja 2007. kao hitna poštanska pošiljka stigao u Pulu Naglasak u hrvatskome književnom jeziku, Knjiga četvrta Velike hrvatske gramatike u izdanju Nakladnoga zavoda Globus u Zagrebu. Bitno joj je pomogao Tomislav Pušek da se iz stanja zakopana blaga vine u novi život - u hrvatski standardni i književni jezik.

\section{Zaključak}

"Hrvatski štokavski govori većinom se jasno razlikuju od ostalih govora istoga narječja i svojim posebnim zapadnim značajkama i svojim vezama s čakavskim i kajkavskim govorima." ${ }^{22}$ Uz taj citat iz djela Josipa Lisca ide i svojevrsna definicija zapadnog dijalekta: "Novoštokavski ikavski dijalekt današnji je dijalekt hrvatskoga jezika koji je najvećom dijalektnom jedinicom nastalom od nekadanjega zapadnoštokavskog narječja."23

A vidjesmo već i koje su značajke zapadnog dijalekta, posebice naglasne. Razmotrismo i strukturno razvojna istosmjerna svojstva sučinitelja hrvatskoga standardnojezičnog naglašavanja kao što su slavonski i jugozapadno istarski dijalekt, zatim dubrovački i krajiški poddijalekt, a tome dodajemo, prvi put, i istočnobosanski dijalekt $\mathrm{s}$ njegovim zapadnonovoštokavski obilježjima kao što su GA mëne, tëbe, sëbe, njëga; DL mëni, tëbi, sëbi, njëmu; zatim opozicija ženski : srednji rod : nòva - növo, vèdra - vëdro, lik čëtvero i četvèrica (uz

\footnotetext{
${ }^{22} \mathrm{~J}$. LISAC, 2003, 15.
}

${ }^{23} \mathrm{~J}$. LISAC, 2003, 60. 
četvòrica) i tomu slično. U svemu je tome središnje naglašavanje zapadnog dijalekta kao gravitacijska snaga za svoje sučinitelje koliko su oni ostvarili zapadnonovoštokavske $\mathrm{i}$ ine značajke te koliko su oni na istosmjernom razvojnome pravcu do zapadnonovoštokavskih konačnica.

Zapadna je novoštokavština sa svojim razvojnim tendencijama prije svega jezični izraz hrvatske jezične zajednice, tj. svih njezinih govornika koji su po svojem jezičnom znanju i iskustvu sudionici svih stilova hrvatskoga standardnog (i književnog) jezika.

Kako je hrvatski standardni (i književni) jezik obilježen i tronarječnošću, valja naći mjeru u sudjelovanju čakavskoga i kajkavskoga narječja te nenovoštokavske štokavštine u razvojnoj perspektivi našega zajedničkog standardnog i književnoga jezika. To je prava mjera u već ostvarenima i budućim inovacijama koje nisu u znaku dosadašnjih voluntarizama, nego vjera u samorazvoj standardnoga i književnog jezika u duhu osmotske konvergencije. Postoje već malne i naglasni pankroatizmi, kakvi su odavno GA osobnih zamjenica mëne, tëbe, sëbe, njëga; DL mëni, tëbi, sëbi, njëmu. Takvi su i infinitivi trêsti, tûći, vûći; möći, peeći, reeći; njihovi glagolski pridjevi prošli u svim rodovima i brojevima: trêsao - trêsla - trêslo, trêsli - trêsle - trêsla; pëkao - pëkla - pëklo, pëkli - pëkle - pëkla. I to je samo pars pro toto.

U Jeziku (2012. $)^{24}$ navedene su, koliko se moglo, i objašnjene dosadašnje zajedničke inovacije zapadnonovoštokavskih i drugih hrvatskih idioma.

Priroda je čovjeka duh. A najveće duhovno djelo ${ }^{25}$ jest jezik - izraz i izražaj brojnih tvoraca - darovan potomstvu. Predci su nam, sami bezimeni, sve izimenovali i dijelom uobličili. I svaki takav čin jest zrno poezije. U jezik stane sve: i tvari i činjenice i njihovi odnosi. I svi doživljaji od početnog osjeta, što je izraz života i početak duha, sve do pojmova znanosti i vrhunske mudrosti, do vječno živih pojmova - Boga i bitka.

Koliko račvišta, sa stranputicama i povratcima na prave putove, s tendencijama koje pobjeđuju ili su pobijeđene, sve do stalnih inovacija što ostavljaju trag.

Iz svega možemo konačno zaključiti da smo pili iz svih izvora, ali opet nikomu ne dugujemo ništa. Kao živa jezična zajednica imamo u sebi i svoti svojih tekstova sve u jeziku. I sav jezik.

\footnotetext{
${ }^{24}$ S. VUKUŠIĆ, 2012, 121-124.

${ }^{25}$ U smislu Saussureova prvog člana dvojsnosti (dihotomije) langage, tj. langue / parole.
} 


\section{Literatura}

Stjepan BABIĆ, Glasovi i oblici hrvatskoga književnoga jezika, Zagreb, 2007, 96.

Eugenija BARIĆ - Mijo Lončarić - Dragica MALIĆ - Slavko PAVEŠIĆ - Mirko PETI - Vesna ZEČEVIĆ - Marija ZNIKA, Priručna gramatika hrvatskoga književnog jezika, Zagreb, 1979.

Ivan BRABEC - Mate HRASTE - Sreten ŽIVKOVIĆ, Gramatika hrvatskosrpskoga jezika, Zagreb, 1965.

Dalibor BROZOVIĆ, Standardni jezik, Teorija, usporedba, geneza, povijest, suvremena zbilja, Zagreb, 1970,

Dalibor BROZOVIĆ, O ortoepskoj vrijednosti dugoga i produženog ijekavskog jata, Jezik, 3-4 i 5, Zagreb, 1972.-73.

Hrvatski jezični savjetnik, Zagreb, 1999.

Hrvatski enciklopedijski rječnik, Zagreb, 2002.

Pavle IVIĆ, Srpski narod i njegov jezik, Beograd, 1971, 282-283.

Stjepan IVŠIĆ, Prilog za kvantitetu u hrvatskom jeziku. Priredio, napisao predgovor i popratio bilješkama Božidar Finka, Rad JAZU, knjiga 376, Razred za filologiju, 10, 1979.

Vatroslav JAGIĆ, Književnik, izlazio u Zagrebu "potporom Matice hrvatske" kao četvrtogodišnjak, 1864.

Mile JAPUNČIĆ, Osobine bunjevačkoga govora u Lici, Nastavni vjesnik, XII, Zagreb, 1912.

Josip LISAC, Hrvatska dijalektologija 1., Zagreb, 2003.

Ranko MATASOVIĆ, Kratka poredbenopovijesna gramatika latinskoga jezika, Zagreb, 1997.

Žarko MULJAČIĆ, Opća fonologija i fonologija suvremenoga talijanskog jezika, Zagreb, 1972.

Pravopis hrvatskosrpskog jezika, MH i MS, Zagreb - Novi Sad, 1960.

Ferdinand DE SAUSSURE, Tečaj opće lingvistike, Ženeva, 1916.

Grga TOMLJENOVIĆ, Bunjevački dijalekt zaleđa senjskoga s osobitim obzirom na naglas, Nastavni vjesnik, 19, Zagreb, 1911.

Stjepan VUKUŠIĆ, Usporedba dvaju naglašavanja imenica muškog roda na O, Jezik, 23 (3-4), Zagreb, 1975, 92-118.

Stjepan VUKUŠIĆ, Usporedbe dvaju novoštokavskih naglašavanja : stiničkog i daničićeva : prilog za uporabnu normu hrvatskoga književnog jezika, Senjski zbornik, IX, Senj, 1982, 283-366.

Stjepan VUKUŠIĆ, Nacrt hrvatske naglasne norme na osnovi zapadnog dijalekta, Pula, 1984.

Stjepan VUKUŠIĆ - Ivan ZORIČIĆ - Marija GRASSELLI-VUKUŠIĆ, Naglasak u hrvatskome književnom jeziku, Knjiga četvrta Velike hrvatske gramatike, Zagreb, 2007. 
Stjepan VUKUŠIĆ, Naglasno usavršavanje hrvatskog jezika III, Jezik, 59 (4), Zagreb, 2012, 121-129.

Stjepan VUKUŠIĆ, Naglasno usavršavanje hrvatskog jezika V, Jezik, 61 (4-5), Zagreb, 2014, 124-131.

\section{THE AMOUNT OF WESTERN NEOŠTOKAVIAN IN THE CROATIAN STANDARD LANGUAGE}

Summary

In the introductory part the principles of western Neoštokavian in accentuation are presented. In the elaboration the gradual unveiling and interpretation of western Neoštokavian are explained. In the conclusion, finally, the results are presented of the introduction and elaboration from which it is clear how the western and eastern Neoštokavian has been revived and that on the basis of the first we have everything in the language and a complete language, and to the second as a system we owe nothing.

Keywords: Neoštokavian - western, eastern, accentuation, accentuation norm, Croatian standard language 